\title{
Rechtsbescherming
}

\section{Horizontale werking van het EU- Grondrechtenhandvest: de kogel lijkt door de kerk}

\author{
Prof. mr. H.C.F.J.A. de Waele*
}

Kunnen bepalingen uit het EU-Handvest van de Grondrechten worden ingeroepen in horizontale verhoudingen, dat wil zeggen in gedingen waarin twee private partijen tegenover elkaar staan? In het arrest Association de médiation sociale lijkt het Hof van Justitie deze principevraag bevestigend te beantwoorden. Daarbij onderstreept het bovendien de vitaliteit van de Mangold/Kücükdeveci-rechtspraak, waarin al eerder werd uitgemaakt dat richtlijnbepalingen die een uitwerking vormen van een algemeen beginsel van EU-recht, onder omstandigheden eveneens als zodanig in gedingen tussen particulieren kunnen worden toegepast. Tegelijkertijd houdt het Hof van Justitie zich echter op de vlakte en krijgen de theoretische mogelijkheden geen praktisch vervolg, omdat er in casu een beroep werd gedaan op een onvoldoende concrete Handvestbepaling. Ogenschijnlijk heeft het hiermee niettemin een beslissende stap gezet, en is voor toekomstige gevallen de kogel door de kerk.

Hv7 EU 15 januari 2014, zaak C-176/12, Association de médiation sociale/Union locale des syndicats CGT, Hichem Laboubi, Union départementale CGT des Bouches-duRhône, Confédération générale du travail, n.n.g.

\section{Inleiding en achtergrond}

De voorliggende casus draait, zoals advocaat-generaal Cruz Villalón het formuleert, om een principekwestie: kan een bepaling uit het EU-Handvest van de Grondrechten worden ingeroepen in een geschil tussen particulieren, wanneer de inhoud daarvan in een richtlijn is geconcretiseerd? ${ }^{1}$ Aanleiding tot deze vraag is een Frans dispuut tussen de particuliere vereniging Association de médiation sociale (AMS) enerzijds, en haar werknemer Hichem Laboubi en zijn vakbond (onderdeel van de Confédération général du travail, CGT) anderzijds. AMS opereert zonder winstoogmerk, en heeft acht werknemers in dienst met wie een arbeidsovereenkomst voor onbepaalde tijd is gesloten. Laboubi is een van die werknemers, die op 4 juni 2010 door CGT wordt aangewezen als vertegenwoordiger van de vakbondsafdeling binnen de vereniging. AMS kan zich hier echter niet in vinden, omdat er geen sprake is van het minimumaantal werknemers waarbij op grond van de nationale wetgeving een vertegenwoordiging van werknemers moet worden ingesteld (namelijk vijftig). Weliswaar heeft AMS met een honderdtal personen zogenoemde 'werkbegeleidingsovereenkomsten' gesloten, maar op grond van artikel L.111-3 van het Franse arbeidswetboek hoeven die niet in aanmerking te worden genomen bij de berekening van het totale aantal werknemers.

AMS dient bij het Tribunal d'instance de Marseille een verzoek in om het besluit tot aanwijzing van Laboubi als vakbondsvertegenwoordiger te vernietigen. Het Tribunal d'instance vraagt vervolgens de Conseil constitutionnel te beslissen of artikel L.111-3 van de code du travail niet in strijd komt met het in de Franse Grondwet verankerde gelijkheidsbeginsel. Op 29 april 2011 oordeelt de Conseil constitutionnel dat van ongrondwettigheid geen sprake is; het Tribunal d'instance beslist vervolgens echter dat artikel L.111-3 onverenigbaar is met Richtlijn 2002/14/EG, laat die bepaling daarom buiten toepassing, en wijst het verzoek van AMS af.

AMS gaat hierop in cassatie bij het Cour de cassation. Dit rechtscollege legt het Hof van Justitie de vragen voor of het grondrecht op informatie en raadpleging van werknemers, zoals neergelegd in artikel 27 van het EUHandvest van de Grondrechten en zoals gepreciseerd in

\footnotetext{
Prof. mr. H.C.F.J.A. (Henri) de Waele is hoogleraar internationaal en Europees recht aan de Radboud Universiteit Nijmegen en gastprofessor Europees institutioneel recht aan de Universiteit Antwerpen.

1. Conclusie A-G Cruz Villalón van 18 juli 2013 in zaak C-176/12, par. 1.
} 
de bepalingen van Richtlijn 2002/14/EG, ${ }^{2}$ in een geding tussen particulieren kan worden aangevoerd om een nationale regel ter uitvoering van die richtlijn aan het Unierecht te toetsen; en indien het antwoord daarop bevestigend luidt, of die richtlijnbepalingen dan zo moeten worden uitgelegd dat ze zich verzetten tegen een 'negatieve optelregel' als opgenomen in artikel L.111-3, op grond waarvan ondernemingen werkbegeleidingsovereenkomsten niet in de relevante berekeningen hoeven te betrekken.

\section{Arrest van het Hof van Justitie}

Het Hof van Justitie herinnert allereerst aan een eerder oordeel, waarin het uitsprak dat artikel 2 onder d van Richtlijn 2002/14/EG lidstaten niet toestaat om categorieën personen die voor de berekening van het totale personeelsbestand in aanmerking komen, daarvan uit te sluiten; anders zouden immers de rechten van werknemers worden uitgehold, en zou de richtlijn zijn nuttige werking verliezen. ${ }^{3}$ Inzake sociaal beleid beschikken de lidstaten weliswaar over een beoordelingsmarge, maar dat mag er niet toe leiden dat een fundamenteel Unierechtelijk beginsel of voorschrift van zijn inhoud wordt beroofd. Voorts bepaalt artikel 11 van deze richtlijn dat de lidstaten alle nodige maatregelen moeten nemen om de door de richtlijn beoogde resultaten te bereiken, waarmee onverenigbaar is het uitsluiten van een categorie van werknemers bij de berekening van het totale personeelsbestand; lidstaten zouden zich zodoende namelijk kunnen onttrekken aan een duidelijke en precieze, door het EU-recht voorgeschreven resultaatsverbintenis. Artikel 3 lid 1 van Richtlijn 2002/14/EG verzet zich daarom tegen een nationale bepaling als artikel L. 1111-3 van de code du travail.

In de tweede plaats onderzoekt het Hof van Justitie of artikel 3 lid 1 van de richtlijn rechtstreekse werking heeft en vervolgens of de verweerders in het hoofdgeding zich daarop tegenover AMS kunnen beroepen. Naar vaste rechtspraak kunnen particulieren dat doen tegenover de staat, wanneer die laatste een richtlijnbepaling niet binnen de implementatietermijn in nationaal recht heeft omgezet, ofwel wanneer dit niet correct is gebeurd, en wanneer de richtlijnbepaling in kwestie inhoudelijk gezien onvoorwaardelijk en voldoende nauwkeurig is. ${ }^{4}$ Hoewel artikel 3 lid 1 aan lidstaten een zekere beoordelingsmarge laat bij de vaststelling van de noodzakelijke maatregelen, valt de bepaling aan te merken als voldoende nauwkeurig en onvoorwaardelijk, aangezien ze eenduidig voorschrijft dat alle werknemers bij de berekening van het totale aantal moeten worden mee-

2. Richtlijn 2002/14/EG tot vaststelling van een algemeen kader betreffende de informatie en de raadpleging van de werknemers in de Europese Gemeenschap, Pb. EG 2002, L 80/29.

3. Onder verwijzing naar HvJ EG 18 januari 2007, zaak C-385/05, Confédération générale du travail, Jur. 2007, p. I-00611, par. 34 en 38.

4. Onder verwijzing naar HvJ EG 5 oktober 2004, gevoegde zaken C-397/01 t/m C-403/01, Pfeiffer, Jur. 2004, p. I-08835, par. 103. geteld. Naar vaste rechtspraak kan echter zelfs een duidelijke, nauwkeurig omschreven en onvoorwaardelijke richtlijnbepaling die beoogt particulieren rechten te verlenen of verplichtingen op te leggen, niet als zodanig in een geding tussen uitsluitend particulieren worden toegepast; en in casu betreft het net een dergelijk type geschil. In dit soort situaties rust op nationale rechters een verplichting tot conforme interpretatie. Die wordt evenwel op haar beurt begrensd door algemene rechtsbeginselen, en kan niet dienen als grondslag voor een contra legem-interpretatie van het nationale recht. Het Hof van Justitie begrijpt uit de verwijzingsuitspraak dat in casu het Franse recht niet kan worden uitgelegd op een wijze die strookt met de richtlijn. ${ }^{5}$

In deze omstandigheden moet in de derde plaats worden nagegaan of de situatie in het hoofdgeding vergelijkbaar is met die in de zaak die tot het arrest aanleiding heeft gegeven. In aansluiting hierop verkondigt het Hof van Justitie echter, in plaats van bij de pakken neer te zitten, dat het nog nader onderzoek verdient of er in het huidige geval geen parallel is te trekken met de zaak Kücükdeveci. Op die voet zou artikel 27 van het EU-Grondrechtenhandvest, alleen of in samenhang met de bepalingen van de richtlijn, zich mogelijkerwijs laten inroepen in een geding tussen particulieren, met het oog op het buiten toepassing laten van de litigieuze regel van nationaal recht. Naar vaste rechtspraak kunnen rechten uit het Handvest toepassing vinden in alle situaties die door het Unierecht worden beheerst; dus ook in de voorliggende casus, aangezien de bepaling uit de Franse code du travail die in het hoofdgeding wordt toegepast, Richtlijn 2002/14/EG uitvoert. ${ }^{6}$ Het recht op informatie en raadpleging van werknemers binnen een onderneming, verankerd in artikel 27 van het EU-Handvest, behoeft blijkens de bewoording van deze bepaling ook nadere precisering in Europese en nationale voorschriften. Het rechtstreeks werkende verbod in artikel 3 lid 1 van de richtlijn om een bepaalde categorie van personen van de berekening van het totale aantal werknemers van de onderneming uit te sluiten, kan niet worden afgeleid uit de bewoordingen van artikel 27 van het EU-Handvest of de officiële Toelichtingen bij die bepaling. Volgens het Hof van Justitie is derhalve een analogie met Kücükdeveci uiteindelijk toch niet geëigend: in dit laatste arrest draaide het namelijk om het beginsel van non-discriminatie op grond van leeftijd, neergelegd in artikel 21 lid 1 van het Handvest, dat op zichzelf volstaat om aan particulieren een subjectief recht te verlenen waarop zij als zodanig een beroep kunnen doen. Artikel 27 kan daarom niet als zodanig worden ingeroepen om te bereiken dat een niet met Richtlijn 2002/14/EG overeenstemmende nationale bepaling buiten toepassing blijft; en dit geldt tevens voor een eventuele lezing van dat artikel in samenhang met de bepalingen van

5. Onder verwijzing naar o.m. HvJ EU 19 januari 2010, zaak C-555/07, Kücükdeveci, Jur. 2010, p. I-00365, par. 46; HvJ EU 24 januari 2012, zaak C-282/10, Dominguez, par. 25 en 42; HvJ EG 15 april 2008, zaak C-268/06, Impact, Jur. 2008, p. I-02483, par. 100.

6. Onder verwijzing naar HvJ EU 26 februari 2013, zaak C-617/10, Åkerberg Fransson, n.n.g., par. 19. 
Richtlijn 2002/14/EG. Het Hof van Justitie wijst er tot slot nog wel op dat een benadeelde partij zich kan beroepen op de Francovich-rechtspraak, om in voorkomend geval schade veroorzaakt door schendingen van EUrecht vergoed te krijgen. ${ }^{7}$

\section{Analyse}

Met dit oordeel lijkt voor Laboubi c.s. de zaak op een totale deconfiture uit te draaien: de gewraakte regel uit het arbeidswetboek blijft in stand, zodat de teller van het aantal werknemers niet boven de acht uitkomt, en AMS zich gesteund weet in haar keus de inrichting van een personeelsvertegenwoordiging af te wijzen. Vanuit Europeesrechtelijk perspectief is het arrest niettemin in drie opzichten saillant. Ten eerste vanwege 's Hofs omgang met het onderscheid tussen rechten en beginselen in het EU-Grondrechtenhandvest; ten tweede vanwege de nadrukkelijke indicatie dat het EU-Handvest in horizontale situaties zijn werking kan ontplooien; en ten derde vanwege de ondubbelzinnige onderstreping van de levensvatbaarheid van de Kücükdeveci-doorwerkingsroute. De paragrafen hieronder gaan dieper in op deze verschillende aspecten, waarna een korte conclusie de bijdrage afsluit.

\section{Rechten versus beginselen in het Handvest}

Eén van de bekende tekortkomingen van het EU-Hand-

vest bestaat erin dat het onderscheid makt tussen 'rechten' en 'beginselen', zonder dat het tegelijk aangeeft welke bepalingen een recht bevatten en welke een beginsel. ${ }^{8}$ De officiële Toelichtingen bieden evenmin een systematisch overzicht, en beperken zich tot enkele voorbeelden. ${ }^{9}$ Soms biedt de tekst voldoende houvast, bijvoorbeeld in het geval van artikel 37 , dat stelt dat in het beleid van de Unie een hoog niveau van milieubescherming moet worden gewaarborgd. Vanwege het onmiskenbare programmatische karakter valt dit moeilijk als een recht te kwalificeren. Soms komt men voor kleine verrassingen te staan: zo blijkt volgens de Toelichtingen het recht op integratie van personen met een handicap een beginsel te bevatten. ${ }^{10}$ Nog onhandiger is het gegeven dat volgens diezelfde Toelichtingen sommige artikelen elementen van zowel een recht als een beginsel bevatten, zonder dat wordt vermeld wat daarvan de consequenties zijn. Over de bedoeling van de opstellers bij het hanteren van het onderscheid tussen rechten en beginselen in het Handvest bestaat daarentegen weinig

7. HvJ EG 19 november 1991, gevoegde zaken C-6/90 en C-9/90, Francovich, Jur. 1991, p. I-05357.

8. Additionele verwarring vloeit voort uit het feit dat de 'beginselen' in het Handvest niet hetzelfde zijn als de gevestigde categorie algemene beginselen van EU-recht (waarover bijvoorbeeld het standaardwerk T. Tridimas, The General Principles of EU Law, Oxford: Oxford University Press 2007).

9. Toelichtingen bij het EU-Handvest van de Grondrechten, Pb. EU 2007, C 303/2.

10. Toelichtingen bij het EU-Handvest van de Grondrechten, toelichting ad art. 26. twijfel, namelijk het begrenzen van de aanspraken van individuele burgers. Artikel 52 lid 5 verklaart daartoe dat 'aan bepalingen die beginselen bevatten uitvoering kan worden gegeven door wetgevings- en uitvoeringshandelingen van de Europese instellingen, organen en instanties, en door handelingen van de lidstaten wanneer zij het EU-recht ten uitvoer brengen; de rechterlijke bevoegdheid ten aanzien van die bepalingen dient echter beperkt te blijven tot de uitlegging van de genoemde handelingen en de toetsing van de wettigheid daarvan'. Zoals de Toelichtingen het verwoorden: 'Deze bepalingen geven geen aanleiding tot directe eisen tot het nemen van positieve matregelen door de instellingen van de Unie of de overheden van de lidstaten.'11

In het voorliggende arrest buigt het Hof van Justitie zich over artikel $27 \mathrm{Hv}$, dat het recht op informatie en raadpleging van werknemers binnen een onderneming waarborgt: 'Werknemers en hun vertegenwoordigers moeten in de gevallen en onder de voorwaarden waarin het recht van de Unie en de nationale wetgevingen en praktijken voorzien, de zekerheid hebben, dat zij op passende niveaus tijdig worden geïnformeerd en geraadpleegd.' Het vormt een weerspiegeling van artikel 21 van het Europees Sociaal Handvest, ${ }^{12}$ maar is daarnaast ook al sinds begin jaren negentig in secundaire EUrecht opgenomen. ${ }^{13}$ Naar de tekst bezien, stelt artikel 27 Hv zich echter bescheiden op: werknemers en hun vertegenwoordigers krijgen niet meer dan een 'zekerheid' dat zij 'op passende niveaus tijdig worden geinformeerd en geraadpleegd', en wel 'in de gevallen en onder de voorwaarden waarin het recht van de Unie en de nationale wetgevingen en praktijken voorzien'. Het Hof van Justitie spreekt zich jammer genoeg niet helder uit over de aard van het beestje, maar constateert wel dat uit de gebezigde bewoordingen blijkt dat dit artikel 'pas zijn volle werking verkrijgt nadat het nader in Unierechtelijke en nationaalrechtelijke voorschriften [is] bepaald'. ${ }^{14}$ Hierop baseert het zijn aansluitende conclusie dat artikel 27 zich niet leent voor een vergelijkbare toepassing als het beginsel van non-discriminatie op grond van leeftijd, vastgelegd in artikel 21 lid 1, in de zaak Kücükdeveci. Het Hof van Justitie lijkt zodoende de mening toegedaan dat het in artikel 27 gaat om een beginsel, zodat dan zinswendingen in het Handvest die wijzen op de noodzaak van nadere Unierechtelijke en nationaalrechtelijke voorschriften, opgevat zouden mogen worden als een intrinsiek kenmerk van de betreffende categorie - zoals artikel 52 lid $5 \mathrm{Hv}$ al suggereert. Het Hof van Justitie wekt tersluiks de indruk, zonder dit als zodanig te benoemen, dat het hier eigenlijk toetst of de bepaling voldoende nauwkeurig en onvoorwaardelijk is. In het licht van artikel 52 lid 5 komt die eigenschap bij uitstek niet toe aan beginselen; die behoeven immers per

11. Toelichtingen bij het EU-Handvest van de Grondrechten, toelichting ad art. 26.

12. Trb. 1963, 90.

13. Met name in Richtlijn 94/45/EG inzake de Europese Ondernemingsraad, $P b$. EG 1994, L 254/64 en Richtlijn 98/59/EG inzake collectief ontslag. Pb. EG 1998, L 225/16.

14. Par. 45. 
definitie nadere uitvoering. In $A M S$ speuren we echter vergeefs naar volwaardige handvatten, waarmee we in de toekomst de vinger op het exacte onderscheid zouden kunnen leggen. Advocaat-generaal Cruz Villalón besteedde hier veel uitgebreider aandacht aan; maar mede gezien het feit dat de verwijzende instantie er niet specifiek naar informeerde, redeneerde het Hof van Justitie wellicht (en in se terecht) dat het zich hier niet over dit meer academische vraagstuk hoefde uit te laten. ${ }^{15}$

Horizontale werking van het Handvest

Wat betreft het toepassingsbereik van het EU-Grondrechtenhandvest verklaart artikel 51 dat het gericht is tot de instellingen, organen en instanties van de Unie, alsmede tot de lidstaten wanneer zij het recht van de Unie ten uitvoer brengen. In eerste instantie doet dit voorkomen dat het geen rol kan spelen in verhoudingen tussen particulieren, en in de literatuur zijn diverse auteurs inderdaad die mening toegedaan. ${ }^{16}$ In zijn conclusie betoogde advocaat-generaal Cruz Villalón evenwel al dat uit de tekst van artikel 51, noch uit zijn voorgeschiedenis, valt af te leiden dat het Handvest iedere relevantie voor private verhoudingen zou moeten ontberen. ${ }^{17}$ Voorts wijst hij erop dat bijvoorbeeld de verkeersvrijheden en het verbod van discriminatie op grond van geslacht, die eveneens een fundamenteel karakter dragen, ook reeds in geschillen tussen particulieren zijn toegepast; het Unierecht zou derhalve al lang bekend zijn met het fenomeen horizontale werking van grondrechten. ${ }^{18}$ In zijn arrest onderschrijft het Hof van Justitie deze redenering weliswaar niet volmondig, maar wijst het de suggestie evenmin van de hand: in de cruciale paragraaf 41 start het een onderzoek naar de mogelijkheid of artikel 27 van het EU-Handvest, alleen of gelezen in samenhang met de bepalingen van Richtlijn 2002/14/EG, kan worden ingeroepen in een geding tussen particulieren om een nationale bepaling buiten toepassing te laten. ${ }^{19}$ Zoals hierboven besproken blijkt artikel 27 zich daarvoor uiteindelijk niet te lenen, echter

15. Bovendien valt niet met zekerheid op te maken of de verweerders zich daadwerkelijk zelf op art. 27 Handvest beriepen, of dat het Cour de cassation deze bepaling uit eigen beweging in het geding heeft gebracht.

16. Zie bijvoorbeeld M. de Mol, 'Kücükdeveci: Mangold revisited - Horizontal direct effect of a general principle of EU law', European Constitutional Law Review 2010, p. 302; J. Kokott en C. Sobotta, 'The Charter of fundamental rights of the European Union after Lisbon', EUI Working Papers - Academy of European Law 2010/6, p. 14; A. Hatje, 'Artikel 51', in: J. Schwarze, U. Becker, A. Hatje en J. Schoo (red.), EU-Kommentar, Baden-Baden: Nomos 2012, p. 2738.

17. Conclusie A-G Cruz Villalón, par. 30-32.

18. Zie bijv. HvJ EG 6 juni 2000, zaak C-281/98, Angonese, Jur. 2000, p. I-04139; HvJ EG 11 december 2007, zaak C-438/05, Viking, Jur. 2007, p. I-10779; HvJ EU 12 juli 2012, zaak C-171/11, Fra.bo, n.n.g.; HvJ EG 15 juni 1978, zaak C-149/77, Defrenne, Jur. 1978, p. 01365. Hierover nader o.m. J.W. van de Gronden en H.C.F.J.A. de Waele, 'Fundamentele rechten en het Europese materiële recht: een steeds hechter verband', in: J.H. Gerards en C.H. Sieburgh (red.), De invloed van fundamentele rechten op het materiële recht, Deventer: Kluwer 2013, p. 177-214.

19. Hoewel zelfs vijftig jaar na Van Gend \& Loos er in de doctrine geen absolute overeenstemming bestaat over de inhoud van het begrip 'directe werking', haakt het Hof van Justitie op dit scharniermoment aan bij het courante idee van 'inroepbaarheid'; vgl. echter de nadere bespreking infra. louter en alleen vanwege de aard en formulering van die bepaling. Hiermee lijkt nochtans de principiële barrière geslecht. $\mathrm{Na} A M S$ valt niet meer in ernst vol te houden dat het Handvest per definitie nooit zijn werking kan ontplooien in private geschillen; als dat zo was, had het Hof van Justitie immers de deur wel volledig op slot gehouden, en in paragraaf 41 zijn beschouwingen afgerond, in plaats van een nieuwe weg in te slaan. ${ }^{20}$ Het is enkel omdat artikel 27 zich afhankelijk stelt van nadere concretisering in Europese en lidstatelijke regelgeving, dat het in casu niet tot horizontale werking komt. Ten aanzien van andere bepalingen echter, en dan met name die in de categorie 'rechten', zou een dergelijk beroep denkelijk wél kunnen slagen. Voor de toekomst is kortom het pad geëffend.

Het Hof van Justitie meent dat in theorie artikel 27 van het Handvest sowieso in het hoofdgeding kan worden toegepast, omdat de bepaling uit het Franse arbeidswetboek Richtlijn 2002/14/EG uitvoert. Conform artikel 51 valt de zaak dus onverkort binnen het geldingsbereik van het Handvest, temeer daar het Hof van Justitie recent nog in Akerberg Fransson verklaarde dat EUgrondrechten toepassing kunnen vinden in alle situaties die door het Unierecht worden beheerst. ${ }^{21}$ Van uitvoering is in strikte zin eigenlijk geen sprake, omdat de gewraakte regel uit de code du travail juist hard in botsing komt met Richtlijn 2002/14/EG. Verder verdient opmerking dat de wat losse formulering in Akerberg Fransson, die een oude rechtspraaklijn voortzet, onlangs werd aangescherpt in Siragusa.22 Om te bepalen of een nationale regeling EU-recht ten uitvoer brengt in de zin van artikel 51, zal voortaan onder meer moeten worden bezien of die de uitvoering van een Unierechtelijke bepaling beoogt; wat de aard van deze regeling is en of zij niet andere doelstellingen nastreeft dan die waarop het Unierecht ziet (ook wanneer die regeling dit recht indirect kan beïnvloeden); en of er een Europese regeling bestaat die specifiek is voor deze materie of deze kan beïnvloeden. In $A M S$ wordt niettemin, ook in het licht van deze (niet-uitputtende) opsomming, de 'minimumdrempel' ruim gehaald.

Bij de opstelling van het Handvest werden diverse veiligheidskleppen ingebouwd om te voorkomen dat het in de jurisprudentie van het Hof van Justitie een eigen

20. Men kan eventueel nog twisten over het feit of de AMS-casus een zuiver horizontaal geschil betrof, aangezien een onderneming aantrad tegenover een vakbond; deze laatste instantie beschikt over een zekere collectieve macht, zodat de verhouding niet geheel symmetrisch is (vgl. HvJ EG 12 december 1974, zaak C-36/74, Walrave, Jur. 1974, p. 01405; HvJ EG 18 december 2007, zaak C-341/05, Laval, Jur. 2007, p. 1-11767). Het feit dat ook de privépersoon Laboubi een van de wederpartijen is, zou niettemin eventuele twijfels op dit punt mogen wegnemen.

21. HvJ EU 26 februari 2013, zaak C-617/10, Åkerberg Fransson, n.n.g.; zie hierover o.m. M.A. Fierstra, 'Åkerberg Fransson: ruim toepassingsgebied van Handvest op handelingen van lidstaten', NTER 2013/6, p. 197-205; E. Hancox, 'The meaning of 'implementing' EU law under article 51(1) of the Charter: Akerberg Fransson', Common Market Law Review 2013, p. 1411-1432; J.M. Veenbrink en H.C.F.J.A. de Waele, 'Annotatie bij Åkerberg Fransson en Melloni', JB 2013, p. 305-318.

22. HvJ EU 6 maart 2014, zaak C-206/13, Siragusa, n.n.g. (geannoteerd door M.P. Beijer in JB 2014/5) 
leven zou gaan leiden, en dat het direct of indirect zou resulteren in een uitbreiding van de reikwijdte van het EU-recht. De bedoeling van de lidstaten was enkel om bestaande rechten te codificeren, niet om nieuwe aanspraken in het leven te roepen; om die reden hebben zij uitdrukkelijk en op meerdere plaatsen verankerd dat het geen nieuwe taken schept voor de Europese Unie, en dat het evenmin mag leiden tot een verruiming van haar bevoegdheden. ${ }^{23}$ Het moge dan waar zijn dat het fenomeen horizontale werking van grondrechten binnen de EU niet helemaal nieuw is, met het toestaan van horizontale werking aan het Handvest (zeker wanneer het bepalingen zou gaan betreffen die tot dusver niet in betrekkingen tussen private partijen een rol speelden), worden de voornoemde intenties toch wel enigszins ondermijnd. ${ }^{24}$ In Mangold en Kücükdeveci gebeurde dit nog heimelijk, over de band van de algemene beginselen van EU-recht. $A M S$ opent de deur voor een minder omfloerste aanpak. Hoewel de juridische beletsels niet onoverkomelijk zijn, zouden er bij de legitimiteit van deze manoeuvre vraagtekens kunnen worden geplaatst. ${ }^{25}$ In follow-up-zaken zal het Hof van Justitie daarom uiterst omzichtig te werk moeten blijven gaan.

\section{Vitaliteit van de Mangold/Kücükdeveci-} doorwerkingsroute

In de laatste tien paragrafen van $A M S$ onderzoekt het Hof van Justitie of er in casu ruimte is voor een parallele benadering als in het arrest Kücükdeveci. Dit wordt gepresenteerd als een 'derde oplossing', nadat de eerdere technieken van directe werking en conforme interpretatie gestrand zijn. Naar analogie met Kücükdeveci, en het eerdere oordeel in Mangold, ${ }^{26}$ staat daarom te bezien of artikel 27 van het Handvest, alleen of in samenhang met de bepalingen van Richtlijn 2002/14/EG, in dit private geschil is in te roepen. Dit baart opzien, aangezien het Hof van Justitie de afgelopen jaren maar weinig aandacht besteedde aan deze doorwerkingsroute. Zo verzuimde het in Dominguez, ondanks de aansporingen van A-G Trstenjak, er überhaupt gewag van te maken, en was in de zaak Römer slechts een zwakke echo te horen. ${ }^{27} A M S$ onderstreept nu de vitaliteit van de Man-

23. Zo o.a. in art. 6 VEU, art. 51 lid 2 van het Handvest, en Verklaring (Nr. 1) bij de Slotakte van het Verdrag van Lissabon, Pb. EU 2010, C 83/337.

24. Op vergelijkbare wijze werden in andere recente oordelen de vermeende 'opt-outs' van het Verenigd Koninkrijk en Polen effectief kaltgestellt; zie HvJ EU 21 december 2011, gevoegde zaken C-411/10 en C-493/10, N.S., Jur. 2011, p. I-13905, en HvJ EU 19 december 2012, zaak C-325/11, Alder, n.n.g.

25. Waarover meer algemeen P. Craig, 'The ECJ and ultra vires action', Common Market Law Review 2011, p. 395, en de diverse bijdragen in M. Adams, H. de Waele, J. Meeusen en G. Straetmans (red.), Judging Europe's Judges - The Legitimacy of the Case Law of the European Court of Justice, Oxford: Hart Publishing 2013.

26. HvJ EG 22 november 2005, zaak C-144/04, Mangold, Jur. 2005, p. I-09981.

27. HvJ EU 24 januari 2012, zaak C-282/10, Dominguez; HvJ 10 mei 2011, zaak C-147/08, Römer, Jur. 2011, p. I-03591. Voor een uitvoerige bespreking, zie L. Pech, 'Between judicial minimalism and avoidance: the Court of Justice's sidestepping of fundamental constitutional issues in Römer and Dominguez', Common Market Law Review 2012, p. 1841-1880.
gold/Kücükdeveci-rechtspraak. Anders dan in die arresten, resulteert dit echter niet in een quasihorizontale werking van een richtlijn. Enerzijds komt dit omdat in casu een Handvestbepaling centraal staat (in Mangold en Kücükdeveci werd het recht op non-discriminatie op grond van leeftijd principieel als een algemeen beginsel van EU-recht aangemerkt, dat in het Handvest was gecodificeerd). Anderzijds blijkt artikel 3 lid 1 van die richtlijn, zoals hierboven besproken, geen rechtstreekse vertolking te zijn van de Handvestbepaling (zoals in Mangold en Kücükdeveci wel het geval was ten aanzien van het verbod op leeftijdsdiscriminatie). ${ }^{28} A M S$ bouwt dus voort op de eerdere precedenten, maar richt wel meer de schijnwerpers op de potentie van het in artikel $27 \mathrm{Hv}$ gecodificeerde fundamentele recht, in plaats van op het samenspel tussen een algemeen beginsel van EU-recht en een richtlijn die geacht wordt daaraan een nadere uitwerking te geven.

Als het Hof van Justitie wél eenzelfde quasihorizontale werking had toegestaan, dan waren de gevolgen daarvan identiek geweest aan die in de eerdere casus: artikel 27 van het Handvest, al dan niet in samenhang gelezen met de bepalingen van Richtlijn 2002/14/EG, zou er dan namelijk toe hebben geleid dat artikel L.111-3 van het Franse arbeidswetboek buiten toepassing moet worden gelaten. Hier zien we wederom een bijzondere vorm van doorwerking terug, die in de literatuur wel als 'exclusionary effect' of 'invocabilité d'exclusion' is aangemerkt; een Europeesrechtelijke norm drukt daarbij als het ware een conflicterende nationale regel uit het nationale geding weg. In abstracto valt deze 'uitsluitende' directe werking te contrasteren met 'substituerende' directe werking, waarbij in het laatste geval het EU-recht tevens een inhoudelijke norm in de plaats van de nationale stelt. Vanwege het verbod op horizontale directe werking van richtlijnen is de 'substituerende' variant doorgaans uit den boze; 'uitsluitende' directe werking biedt dan een sluiproute, die door het Hof van Justitie eerder is beproefd ten aanzien van richtlijnbepalingen die zelf geen rechten scheppen voor, of verplichtingen opleggen aan particulieren. ${ }^{29}$ Dit onderscheid is nochtans niet waterdicht, en volgens sommige commentatoren dogmatisch en praktisch onhoudbaar; bovendien vervaagt hierdoor de grens tussen directe werking en voorrang. ${ }^{30}$ Hoe dit ook zij, Mangold, Kücükdeveci en AMS indiceren dat de techniek bestaat, en dat het Hof van Justitie geen been ziet in aanwending ervan. In het voorliggende

28. Dat Richtlijn 2002/14/EG werd vastgesteld vóórdat het Handvest juridisch bindend werd, zou men wellicht eveneens problematisch hebben kunnen vinden, maar daarbij moeten we niet vergeten dat hetzelfde gold voor Richtlijn 2000/78/EG in Mangold en Kücükdeveci (sterker, Richtlijn 2000/78/EG werd aangenomen nog vóórdat het Handvest plechtig werd afgekondigd, te weten op 27 november respectievelijk 7 december 2000).

29. Zie bijvoorbeeld HvJ EG 30 april 1996, zaak C-194/94, CIA Security, Jur. 1996, p. I-02201; HvJ EG 26 september 2000, zaak C-443/98, Unilever Italia, Jur. 2000, p. I-07535.

30. Zie bijvoorbeeld S. Prechal, Directives in EC Law, Oxford: Oxford University Press 2005, p. 268; voor nadere discussie, zie H. de Waele en I. Kieft, 'De doorwerking van richtlijnen en algemene beginselen van EUrecht. De stand van zaken na het arrest Kücükdeveci', NTER 2010/5, p. 173-174. 
oordeel treffen we niettemin ook de zoveelste beklemtoning aan van de onmogelijkheid van horizontale rechtstreekse werking van richtlijnen, zodat aan de geldigheid van dat verbod niet hoeft te worden getwijfeld; inmiddels ligt het niet in de lijn der verwachting dat het ooit nog zal komen tot herroeping van dit uitgangspunt. ${ }^{31}$ Tegelijk lijkt de Mangold/Kücükdeveci/AMS-route daarvan uitgezonderd, en krijgt de 'uitsluitende directe werking' opnieuw de zegen, zij het impliciet. ${ }^{32}$ Door deze variant zonder schroom te presenteren ná het onderzoek naar eventuele alternatieve methoden van doorwerking, is die feitelijk niet meer weg te denken uit het arsenaal van het Hof van Justitie - al dient de onderlinge verhouding tussen de verschillende vormen nog altijd dringend te worden opgehelderd.

De benadering in Mangold en Kücükdeveci heeft met name kritiek geoogst vanwege de risico's die ze met zich meebrengt voor de rechtszekerheid. Wanneer een algemeen beginsel van EU-recht wordt toegepast in horizontale situaties, weten de procespartijen over en weer lang niet altijd wat ze kunnen verwachten; algemene beginselen zijn immers van nature algemeen, dus ambigu. Met onnauwkeurige regels kan men alle kanten op, wat ze ongeschikt maakt voor het reguleren van een concreet geval. ${ }^{33}$ Door in Kücükdeveci dergelijke horizontale werking toe te staan in samenspel met een (meer gedetailleerde) richtlijnbepaling, heeft het Hof van Justitie geprobeerd deze tekortkoming te ondervangen. ${ }^{34}$ Het oordeel in $A M S$ is nog minder kwetsbaar voor voornoemde kritiek, aangezien het gaat om de eventuele horizontale toepassing van een Handvestbepaling, die naar zijn aard al een stuk minder ambigu is dan een algemeen beginsel. Voorts wijst het Hof van Justitie uiteindelijk een dergelijke doorwerking af, omdat artikel 27 van het Handvest geen subjectief recht verleent waar particulieren als zodanig een beroep op kunnen doen, en Richtlijn 2002/14/EG daar evenmin een voldoende uitwerking van vormt. De vraag blijft dan wel welke andere Handvest- of richtlijnbepalingen, alleen of in samenhang gelezen, een parallel effect als in Mangold/Kücükdeveci kunnen sorteren. $A M S$ geeft zelf aan dat artikel 21 lid 1 daarvoor in aanmerking komt. Römer deed eveneens reeds vermoeden dat de casuistiek niet tot non-discriminatie op grond van leeftijd beperkt hoeft te blijven, maar ten minste is uit te breiden naar non-discriminatie op grond van seksuele geaardheid. ${ }^{35}$ Daar-

31. Hoewel daar talloze goede redenen voor zijn; zie bijvoorbeeld P. Craig, 'The legal effect of directives: policy, rules and exceptions', European Law Review 2009, p. 349-364.

32. In AMS gaat het uiteraard wel om de eventuele zelfstandige 'uitsluitende werking' van een bepaling uit het Handvest, die ingevolge art. 6 VEU dezelfde status heeft als primaire Unierecht.

33. J. Mazák en M.K. Moser, 'Adjudication by reference to general principles of EU law: a second look at the Mangold case law', in: Adams, De Waele, Meeusen en Straetmans 2013, p. 70.

34. Hetgeen overigens het verbod op horizontale werking van richtlijnen uitholt, aangezien materieel gezien veelal de richtlijnbepaling wordt toegepast, onder de dekmantel van het algemene beginsel; vgl. De Waele en Kieft 2010, p. 173.

35. Vgl. Mazák en Moser in: Adams, De Waele, Meeusen en Straetmans 2013, p. 79: '[T] he implications of those rulings are obviously not limited to discriminiation on grounds of age.' naast zouden we bijvoorbeeld kunnen denken aan het recht op gegevensbescherming, dat tegenwoordig zowel in primaire (art. 16 lid $1 \mathrm{VWEU}$ en art. 8 Handvest) als secundaire EU-recht (o.a. Richtlijn 95/46/EG) is neergelegd. ${ }^{36} A M S$ laat er evenwel geen misverstand over bestaan dat de vlieger niet opgaat terzake van Handvestbepalingen die het karakter van een 'recht' ontberen, en die in een te verwijderd verband staan met de bewuste richtlijnbepaling(en). Aan de andere kant kunnen denkelijk voldoende nauwkeurige en onvoorwaardelijke Handvestrechten voortaan zelfstandig horizontaal doorwerken en, analoog aan Mangold/Kücükdeveci, op eigen kracht afwijkende regels van nationaal recht uit het geding 'wegdrukken'.

Wanneer het Mangold/Kücükdeveci-effect niet te realiseren valt over de band van een richtlijn, en het Handvest zich desgevallend evenmin voor zelfstandige horizontale toepassing leent, resteert de mogelijkheid voor een benadeelde partij om krachtens de Francovich-rechtspraak een vordering tot schadevergoeding in te dienen. Hier moet men niet te veel van verwachten; de ervaring leert dat de afgelopen twintig jaar dergelijke claims maar zelden succesvol zijn gebleken. ${ }^{37}$ Bovendien schieten Laboubi c.s. er in casu weinig mee op, aangezien hun inzet was het oprichten van een werknemersvertegenwoordiging, waarvoor een financiële tegemoetkoming geen zinvolle compensatie biedt. Nu het Hof van Justitie heeft geconstateerd dat de code du travail niet strookt met het EU-recht, zal Frankrijk de schending moeten redresseren. In het verlengde daarvan ware het haast rechtvaardiger om de firma AMS een schadevergoeding toe te kennen, aangezien zij geconfronteerd wordt met een verplichting waarvan ze oorspronkelijk niet kon bevroeden dat die op haar rustte. ${ }^{38}$

\section{Conclusie}

Het arrest $A M S$ zou op het eerste gezicht door kunnen gaan voor de anticlimax van het jaar: na de conclusie van A-G Villalón, die unverfroren pleitte voor toepassing van het Handvest in horizontale situaties, en die in casu evenmin moeite had met directe werking à la Kücükdeveci, waren de verwachtingen hooggespannen. Aan de oppervlakte biedt het arrest van het Hof van Justitie beduidend minder spektakel, maar bij nadere inspectie zijn de contouren van een bredere paradigmaverschuiving te herkennen: horizontale werking van het Handvest is kennelijk niet principieel uitgesloten; het Man-

36. Evenzo E. Muir, 'The fundamental rights implications of EU legislation: some constitutional challenges', Common Market Law Review 2014, p. 232. Voor een tentatief overzicht van richtlijnbepalingen die zich lenen voor het Mangold/Kücükdeveci-effect, zie De Waele en Kieft 2010, p. 174-176

37. T. Lock, 'Is private enforcement of EU law through State liability a myth? An assessment 20 years after Francovich', Common Market Law Review 2012, p. 1675-1702. Voor een zeldzame uitzondering in eigen land, zie Hof 's-Gravenhage 15 oktober 2013, JB 2013/13 m.nt. R.J.B. Schutgens.

38. Vgl. de conclusie van A-G Cruz Villalón, par. 79 
gold/Kücükdeveci-doorwerkingsmechanisme is alive and kicking; en een Handvestbepaling en een richtlijn kunnen - onder omstandigheden - in private geschillen worden ingeroepen om regels van national recht buiten toepassing te doen treden.

Aangezien $A M S$ een oordeel van een Grote Kamer betreft, komt het groot gezag toe, en betreft het beslist geen losse flodder. Het wachten is nu op vervolgzaken tussen particulieren waarin volwaardige fundamentele rechten uit het Handvest in stelling worden gebracht. Wanneer het Hof van Justitie op het huidige basispatroon voortborduurt, zal het ongetwijfeld de nodige consternatie wekken. Het is tevens de vraag hoe nationale constitutionele gerechtshoven zullen reageren; zo kon het Duitse Bundesverfassungsgericht indertijd nog leven met Mangold, maar er zijn ondertussen aanwijzingen dat het de confrontatie opzoekt. ${ }^{39}$ Een oude Chinese vervloeking luidt 'May you live in interesting times' ... 